\section{Prof. Edgar Allen: Bayly Medallist}

Prof. Edgar Allen, to whom the Bayly Medal of the Royal College of Physicians has just been awarded, is professor of anatomy in the Yale University School of medicine, a post to which he succeeded in 1933 after a very fruitful period of office in the University of Missouri. In both universities his department has proved a vigorous centre of research on the sex hormones, and his own contributions to the subject form an essential foundation to modern knowledge of the endocrine action of the ovaries. Before 1917 attempts to isolate ovarian internal secretions were seriously handicapped by the lack of a specific test for what to-day is called oestrogenic action. In that year Stockard and Papanicolaou showed that the œstrous cycle in the guinea pig is associated with cyclical changes in the vaginal epithelium. Shortly afterwards Allen found that in the mouse, too, œstrus is associated with a specific vaginal phase, and from this discovery it was a short step to his and Doisy's successful application of the vaginal smear technique as a test for the ostrogenic action of ovarian extracts. Once extracts with demonstrable œstrogenic activity were made available, the door was open to the chemical isolation, analysis and synthesis of pure œstrogens. Although Allen did not share in this later chemical work, there can be little question that it would have proved impossible without the simple bio-assay method which he developed.

Allen's second major achievement was his demonstration in 1926 of the fact that the follicular phase of the uterine cycle in monkeys and man is under the control of œstrogenic hormone. All later work on the primate cycle emerges from this finding, and Allen's own subsequent investigations have a significant place in the structure of present knowledge of the subject. His contribution does not rest here. Allen is that rare combination of research worker and administrator who is able to stimulate in younger men a strong and lasting interest in research. His laboratory is one of the most productive in the United States, and while the Bayly Medal is a recognition of past work, endocrinologists the world over know that Allen's laboratory will prove no less successful in the future than it has in the past.

\section{Mr. Orville Wright}

Mr. Orville Wright celebrates his seventieth birthday on August 19. It was he who, together with his late brother, Wilbur, first flew a heavier-than-air machine on December 17, 1903, at Kitty Hawk, North Carolina, and, also with his brother, invented the system of control used in flying machines to-day. The first flight lasted only twelve seconds, but further experiment and trials resulted in the development of an aeroplane which established a new record on Septembier 12, 1908, by remaining in the air for seventy-five minutes. The Wright brothers began their investigations on kites and gliders in 1900 . Then they introduced two improvements: (1) the elevator for steering the machine in a vertical plane, which, though now usually attached to the tail, was placed by them in front of the main planes; flexing of the rear edge of the main planes so as to vary the lift on either or both, thus maintaining balance. A petrol motor-driven screw was added in 1903.

The Wright brothers were also great exponents of the use of the wind tunnel in aeronautical investigations. The first motor-driven machine which was used by the Wright brothers in their pioneer flight on December 17, 1903, is now exhibited in the Science Museum, South Kensington. Wilbur died on May 30, 1912. Both brothers have been the recipients of several medals, honorary degrees and other honours. We offer our congratulations to Mr. Orville Wright on the attainment of his seventieth birthday.

\section{Scientific Workers in Industry and Public Affairs}

SIR RoBert PICKard's address to the Society of Chemical Industry on the occasion of the presentation to him of the Society's Medal, was entitled "Th" Influence of Science on National Life", but his treatment of this theme was far less broad than the title. Before 1900, work by Faraday and Playfair, by E. Frankland and Roscoe, influenced the living conditions of the people through their respective investigations on the purity of water supplies and the purification of sewage effluents. Up to then, few research chemists were employed in industry, but between 1914-18 and the present time their number. has much increased; and this is also particularly true of the lesser scientific workers (testers, etc.). Science has safeguarded and improved civilized. life in innumerable ways; nevertheless doubts and questions have arisen whether the nation makes adequate use of the scientific ability at its disposal. On the whole, Sir Robert is satisfied with the tremendous improvement in such matters that has occurred in the last twenty-five years. Scientific men are not specially competent to deal with certain political and social questions, but they can reasonably claim to be consulted before decisions are made.

Though many of the recent criticisms of the Civil Service seem to Sir Robert to be unjustified, those concerning reluctance to take decisions and lack of foresight in formulating problems, appear to be valid ; if so, they, are due in part to the cloistered life the Civil Servant has to lead. The same cause may operate among scientific workers employed in industry, and Prof. A. V. Hill's plan of regular interchange between scientific staffs in the civil and municipal services, and in university laboratories, should at least offer a partial remedy. As fellows of the Royal Society are, when elected, nearly all specialists of the highest, but narrowest, type, their services to the nation are most likely to be effective when the problem is entirely novel. We in Britain have "led the field" in applying science to the older industries; in the newer industries, based upon recent discoveries, American scientific workers have made "greater bulk endeavours". The modern central research association is also a typically British product, but there is need of reform in current methods of electing directors or heads of such bodies ; such heads have in the past been largely "thrown up 